Review

\title{
Ocean Acidification and Coral Reefs: An Emerging Big Picture
}

\author{
John E. N. Veron \\ Coral Reef Research, 10 Benalla Road, Oak Valley, Townsville 4811, Australia; \\ E-Mail: j.veron@coralreefresearch.com; Tel.: +61-7-47784609
}

Received: 21 March 2011; in revised form: 9 May 2011 / Accepted: 23 May 2011 /

Published: 30 May 2011

\begin{abstract}
This article summarises the sometimes controversial contributions made by the different sciences to predict the path of ocean acidification impacts on the diversity of coral reefs during the present century. Although the seawater carbonate system has been known for a long time, the understanding of acidification impacts on marine biota is in its infancy. Most publications about ocean acidification are less than a decade old and over half are about coral reefs. Contributions from physiological studies, particularly of coral calcification, have covered such a wide spectrum of variables that no cohesive picture of the mechanisms involved has yet emerged. To date, these studies show that coral calcification varies with carbonate ion availability which, in turn controls aragonite saturation. They also reveal synergies between acidification and the better understood role of elevated temperature. Ecological studies are unlikely to reveal much detail except for the observations of the effects of carbon dioxide springs in reefs. Although ocean acidification events are not well constrained in the geological record, recent studies show that they are clearly linked to extinction events including four of the five greatest crises in the history of coral reefs. However, as ocean acidification is now occurring faster than at any know time in the past, future predictions based on past events are in unchartered waters. Pooled evidence to date indicates that ocean acidification will be severely affecting reefs by mid century and will have reduced them to ecologically collapsed carbonate platforms by the century's end. This review concludes that most impacts will be synergistic and that the primary outcome will be a progressive reduction of species diversity correlated with habitat loss and widespread extinctions in most metazoan phyla.
\end{abstract}

Keywords: ocean acidification; coral reefs; climate change; coral 


\section{Introduction}

There are now several hundred publications concerning the history, causes and possible effects of ocean acidification (OA) and how it may progress during the 21 st century and beyond. Chemical aspects were described [1-7] long before impacts on marine ecosystems were recognised [8]. However over half of all publications about OA now refer to reefs, or are specifically about reefs and most of these have been published in the last 10 years. Because reefs are both geological and biological structures, OA has now come to span a range of sciences that are almost the equal of climate change, yet OA is only tangentially an aspect of climate change, linked by a common cause (anthropogenic $\mathrm{CO}_{2}$ ) together with impacts on biodiversity that are predicted to act in synergy with global temperature increase.

Like climate change, OA has moved from a purely scientific subject to one of wider public interest. This move has been slow and recent, primarily because OA is invisible and also because it unavoidably involves the use of chemical terms, an anathema to most non-scientists. This point is well illustrated by coral reefs: temperature-induced mass bleaching is dramatically destructive and well-known, whereas acidification impacts are almost entirely predictions which have no visible component. Nevertheless, public as well as scientific interest has been fuelled by the potential seriousness and irreversibility of OA. Science says humanity could be committing the Earth to a dire future on this basis alone, a prediction now attracting the sorts of attention that climate change originally did. At political levels, OA is usually put on the backburner as being even more remote from immediate imperatives than climate change; for scientists it has become a fertile field for research funding; for denialists it is ideal for indulging individual viewpoints and advertising books [9,10]; for the popular media it is becoming an attractive field for controversy. Certainly OA belongs in the domain of science, but what science: the equations of chemists, the experiments of physiologists, the field observations of ecologists, or the reconstructions of geologists? All have perspectives that make up the big picture.

This article summarises the sometimes controversial contributions made by the different sciences to predict the path of OA impacts on the diversity of coral reefs during the present century.

\section{The Science}

\subsection{Ocean Chemistry}

Dissolved inorganic carbon (DIC) is one of the most important chemical equilibria of the oceans and is largely responsible for controlling the $\mathrm{pH}$ of seawater [11-13]. DIC exists in seawater in four forms: $\mathrm{CO}_{3}{ }^{2-}, \mathrm{HCO}_{3}{ }^{-}$, aqueous $\mathrm{CO}_{2}$ and carbonic acid $\left(\mathrm{H}_{2} \mathrm{CO}_{3}\right)$. At a $\mathrm{pH}$ of $8.2, \sim 88 \%$ of DIC is in the form of $\mathrm{HCO}_{3}{ }^{-}$and $\sim 11 \%$ in the form of $\mathrm{CO}_{3}{ }^{2-}$. Only $\sim 0.5 \%$ is in the form of $\mathrm{CO}_{2}$ and $\mathrm{H}_{2} \mathrm{CO}_{3}$. When $\mathrm{CO}_{2}$ dissolves in seawater, the net effect is to increase the concentrations of $\mathrm{H}_{2} \mathrm{CO}_{3}, \mathrm{HCO}_{3}{ }^{-}$and $\mathrm{H}^{+}$, and decrease the concentration of $\mathrm{CO}_{3}{ }^{2-}$, thereby lowering $\mathrm{pH}$. Atmospheric $\mathrm{CO}_{2}\left(\mathrm{pCO}_{2}\right)$ today is $\sim 100 \mathrm{ppm}$ greater than the pre-industrial value of $\sim 280 \mathrm{ppm}$ causing the average ocean surface $\mathrm{pH}$ to drop by $0.1 \mathrm{pH}$ unit, which represents a $\mathrm{H}^{+}$increase of $\sim 30 \%$ [14]. This $\mathrm{pH}$ decrease may seem small; however it is a change in one of the most basic environmental norms of marine life to have occurred throughout the entire genetic history of most species. 
The extent to which calcifying marine life is affected by such changes largely depends on the saturation state of $\mathrm{CaCO}_{3}(\Omega)$ the product of $\mathrm{Ca}^{2+}$ (estimated from salinity) and $\mathrm{CO}_{3}{ }^{2-}$ (calculated from DIC and total alkalinity) divided by a solubility constant. $\Omega$ is different for the three forms of $\mathrm{CaCO}_{3}$ produced by marine life: high magnesium calcite (secreted by coralline algae), aragonite (secreted by corals, macro-algae and some molluscs) and calcite (secreted by most molluscs, forams, also Palaeozoic corals). Saturation states of surface waters are highest in the tropics and lowest at high latitudes mainly because $\mathrm{CO}_{2}$ is more soluble in colder waters, thus lowering the concentration of $\mathrm{CO}_{3}{ }^{2-} \cdot \mathrm{CaCO}_{3}$ solubility also increases with depth, the depth at which $\mathrm{CaCO}_{3}$ becomes soluble being known as the saturation horizon. The depth of this horizon varies latitudinally and tends to shallow toward the poles, but also varies locally due to changes in ocean circulation patterns, such as in regions of upwelling. The depths of the saturation horizons for calcite, aragonite and high magnesium calcite are very different.

The aragonite saturation horizon (ASH) currently varies between $\sim 100-800 \mathrm{~m}$ depth at the equator and [15] and has been estimated to be decreasing at a rate of $\sim 1-2 \mathrm{~m} / \mathrm{yr}$ [16]; however on the west coast of North America large areas of the continental shelf are now impacted by aragonite-undersaturated waters where upwelled water is further acidified by uptake of $\mathrm{CO}_{2}$ from the atmosphere [17].

\subsection{Physiology}

Calcification by marine biota is not known in the detail of ocean chemistry $[18,19]$ and it is also much more complicated, especially where it involves algal symbionts which respond to different environmental parameters. The list of actual or potential variables affecting physiological responses is indeed long: temperature, light, environmental history, acclimation, geographic location (temperate or tropical), respiration rate, photosynthesis, net productivity, reproductive effort, symbionts (type and density and growth rate) and form (massive or branching). Some of these variables acting in synergy are already known to cause different responses to change in $\mathrm{pCO}_{2}$ and $\Omega_{\text {arag. For example, coral }}$ calcification has been found to decrease [18,20,21], increase [22], or be unaffected [20,23-26] by temperature at increased $\mathrm{pCO}_{2}$ in different taxa in different experimental regimes. Other organisms, especially those who can utilize enhanced levels of $\mathrm{HCO}_{3}{ }^{-}$, have shown increased rates calcification created by increased $\mathrm{pCO}_{2}$ [27-29].

In principle, OA can be accommodated by the same mechanisms that organisms use to counter metabolically produced $\mathrm{H}^{+}$and $\mathrm{CO}_{2}$. These include passive buffering of intra- and extracellular fluids, control of ion exchange across semi-permeable membranes and physiological mechanisms to accommodate short-term metabolic spikes. However, corals do not have dedicated excretory organs as do many higher invertebrates and no marine life has the option of suppressing metabolic activity to wait out periods of OA. Similarly, none of the options for compensating short-term acidity such as dissolution of tests or shells are available over generational time spans. One review of short-term responses to acidified water [12] cites 39 studies indicating a range of deleterious impacts of OA on marine life. The same limitations potentially apply to freshwater habitats where the $\mathrm{pH}$ is much less buffered, and is commonly $<7$. Freshwater habitats with low $\mathrm{pH}$ exclude most calcifying invertebrates except molluscs and crustaceans which have compensating shell chemistries and elaborate excretory 
organs. However, there are rare instances where such adaptation also occurs in the marine realm such as in mussels near hydrothermal vents [30].

The oceans permit marine life to construct carbonate exoskeletons and allow these skeletons to be consolidated into wave-resistent reef because they are supersaturated with carbonates - a physiological opportunity exploited by corals today and by other taxa in the geological past. Under natural conditions coral calcification is widely believed to be primarily dependent on $\Omega_{\text {arag }}$ [22-25,31-38], also $\mathrm{Ca}^{2+}$ [39] rather than $\mathrm{pH}$. Deposition of this aragonite is an extracellular process where an organic matrix combined with minerals is precipitated in diurnal to seasonal bands by a single cell layer, the calicoblastic epithelium, adjacent to the skeleton. This layer facilitates transport of $\mathrm{Ca}^{2+}$ ions and DIC into a minute space filled with a chemically buffered fluid - the calicoblastic space-between the epithelium and the skeleton. The primary source of carbon is internal metabolic $\mathrm{CO}_{2}$ which is in excess during daylight when skeletal formation is maximized. A secondary source is DIC in external seawater [40]. Either way, a cation exchanger precipitates aragonite at the skeleton surface.

There are a wide array of options available to corals for regulating skeleton formation, the most apparent being the physiological isolation of the calicoblastic space from the surrounding seawater by the actions of buffers, an extracellular control mechanism requiring increased energy expenditure [41]. It can also be regulated by controlling carbon exchange between corals and their zooxanthellae in zooxanthellate taxa exhibiting light-enhanced calcification, an intracellular control mechanism $[42,43]$. Potentially, OA can disrupt these mechanisms by decreasing $\mathrm{CO}_{3}{ }^{2-}$ supply, decreasing $\mathrm{pH}$, or by altering the buffering system [25].

In broader terms, the subject of coral calcification has remained a black box for over thirty years [44] and to a large extent it still is. Elucidation of the internal workings of this box will certainly shed light on the ways OA might affect corals and it may well be the case that different taxa have different control mechanisms. This would be hardly surprising given that that most scleractinian families diverged in the Mesozoic Era and that the enhancement of calcification by zooxanthellae has evolved independently several times [45]. It is even possible that different colonies of the same species can adopt different controls depending on the environment in which they occur. However, the external view of the box is clear enough: coral calcification usually varies with $\mathrm{CO}_{3}{ }^{2-}$ availability and, given their physiological dependence on the properties of seawater, it is also dependent on adequate $\Omega_{\text {arag }}$. Just how high $\Omega_{\text {arag }}$ must be for adequate calcification will be a sliding scale from a pre-industrial high of 3.6 at the equator to a range of numbers depending on taxon, habitat, depth and location. The bottom of the scale can be reasonably estimated to be $\sim 2$, which will occur in most reef regions this century (see below). However, given that Scleractinia characteristically have a wide range of strategies to deal with almost anything there will likely to be many exceptions to the norm; e.g., the finding that the Atlantic Ocean coral Favia fragum can still grow in seawater with $\Omega_{\text {arag }}=0.22$, although with growth abnormalities [38]. 


\subsection{Ecology}

It is not yet possible to estimate the proportion of marine species occupying coral reefs; however as the diversity of most metazoan phyla peaks in reef habitats, that number is likely to be at least $25 \%$ of total marine biodiversity. Impacts on reef diversity are therefore of major global significance. Furthermore, because most reef habitats are of carbonate construction, any loss of coral diversity will have a major knock-on effect to all reef-dwelling taxa.

One natural impact of acidification on reef corals is via rainwater which commonly has a $\mathrm{pH}$ of 5.6 or less. Low salinity caused by rainwater can decimate reef flat corals, but those which survive are certainly tolerant of short-term acidity. Microatolls of Porites [46] are one such survivor. These have an outer rim of living colony surrounding a large central area which is usually excavated. This excavation may be due to bioerosion, but where water is regularly ponded for several hours each tidal cycle in areas of high rainfall it is likely to be enhanced by dissolution. Whether this is so or not, the living part of the colony shows a high resilience to repeated short-term acidity.

Extensive degradation of open-ocean coral communities in the vicinity of urban coastal developments is now common, especially in south-east Asia and the Indian Ocean perimeter. In most cases the primary cause (including sedimentation, salinity change, physical damage, mass bleaching and Acanthaster outbreaks) is visually evident; however clear-water impacts are seldom studied although many are potentially valuable sites for water quality assessments which incorporate local factors such as community metabolism, sediment dissolution, freshwater input and organic carbon cycling.

Natural $\mathrm{CO}_{2}$ springs are widespread and clearly offer natural experiments of OA impacts. One such occurrence was a spring on the Italian coast where naturally occurring species with carbonate skeletons were displaced in favor of species without skeletons [47]. Similar occurrences in coral reefs have recently been observed in Indonesia (Komodo), not yet studied, and Papua New Guinea (Milne Bay) where detailed studies are currently underway [48]. The study demonstrated a wide range of tolerance among coral taxa, with Porites being the most tolerant and fast-growing and structurally complex corals such as branching Acropora the least. Down to $\mathrm{pH} 7.8$, the primary impact of OA was therefore a reduction in biodiversity, structural complexity and coral juvenile densities rather than coral cover, as well as an increase in macroalgae and bioeroders. The study also showed that coral reef development ceased at a $\mathrm{pH}$ of less than 7.7 units.

Latitudinal sensitivity to OA will become an increasingly important issue during the 21 st century as diversity changes resulting from the poleward migrations of tropical species are offset by predicted impacts of high latitude OA [8,49]. To date there no studies of tropical zooxanthellate corals demonstrating this, existing studies being confined to the temperate or azooxanthellate species Cladocora caespitosa [26] Lophelia pertusa [50] and Oculina arbuscula [51].

Sensitivity to depth is not relevant to reef corals, but it is to azooxanthellate taxa which have a similar diversity and which commonly occur to depths of $>1000 \mathrm{~m}$ (but occasionally $>6000 \mathrm{~m}$ ), perhaps limited by the ASH, especially in the northern Pacific where the species diversity is low. The potential impact of the decreasing ASH [52] will occur over a wide latitudinal range, impacting the large bioherms of Lophelia found off the Scandinavian coast [53]. Presumably there will be a time-delay in the transmission of decreased $\Omega_{\text {arag }}$ from the surface to the depth where these corals 
occur, however acidification impacts are likely to have already commenced and, irrespective of impacts on living corals, acidification will impact deep sea bioherms by compromising the structural integrity of the framework.

By far the most damaging ecological effects of OA are not on individual taxa but on the group of corals responsible for habitat construction. Coral reefs can only exist if macroalgae are kept in abeyance by herbivores, especially fish [54]. Most herbivores, especially herbivorous fish, need the protective three dimensional habitat provided by branching corals, especially Acropora, in larval as well as adult and phases of their life cycle. Should these corals cease to grow other corals and a high proportion of other life will follow as macroalgae become dominant.

\subsection{Geology}

Although many geologists are at the forefront of climate change science, some have expressed skepticism of predicted impacts of OA just as others are, or were, skeptical of the existence of anthropogenic $\mathrm{CO}_{2}$-driven climate change. In cases where biological and geological sciences meet, there is great potential for misinterpreting concepts of time [55]. Biological changes on reefs in geological time exhibit a boom-to-bust existence where the same carbonate platform is repeatedly re-populated by the same or different suits of species over intervals as short as millennia. However, reefs as geological structures are more enduring than any other biologically-derived structures on Earth. For this reason, the geological history of a reef usually says little or nothing about biologically-significant impacts over the same time interval. In this context, palaeontological and chemostratigraphic records are scattered points which have scant relevance to the fragility of living reefs or the stability of geological platforms. This type of discrepancy is analogous to the reconstructions of $\mathrm{pCO}_{2}$ from ice cores: the zig-zag nature of ice core records is not seen in other geological sources such as reef cores and ocean sediments, yet it is the ice core record that revealed the history of environment change that profoundly affected all ecosystems.

Geological indicators of $\mathrm{pCO}_{2}\left(p \mathrm{CO}_{2 \text { paleo }}\right)$ have been referred to by several authors (in non peer-reviewed publications) as evidence that reefs will not be affected by today's increases in $p \mathrm{CO}_{2}$. In the ice-core analogy above, these records are scatter points (derived from densities of leaf stomata; carbon isotope composition of fossil soils, boron isotope composition of marine carbonates and modeling) within geological history, points which may have nothing to do with the biological 'boom-to-bust' cycles of reef growth with which they are being correlated. Reefs accretion may in fact cease during intervals of high $p \mathrm{CO}_{2 \text { paleo }}$ without any record of this cessation being preserved. Although high $p \mathrm{CO}_{2 \text { paleo }}$ does not necessarily cause $\mathrm{OA}$ (because it is countered by the weathering of carbonate rock in geological time), some points of high $\mathrm{pCO}_{2 \text { paleo }}$ seem sufficiently well linked to intervals of reef development to indicate a tolerance for OA that exceeds any predicted to occur this century.

In broad perspective, the geological record appears to show that reefs have contracted or ceased development during geological intervals when $\mathrm{pCO}_{2 \text { paleo }}$ is both high and low, although the former is clearly dominant [56,57]. At least 27 extinction events involving reefs have been identified [58,59], the best known being the five great mass extinctions that obliterated a high proportion of the earth's marine and terrestrial life. The causes of mass extinctions have attracted a wealth of study culminating in many hypotheses [60]. However, when compared with each-other, and in the light of biological 
knowledge, the most credible common cause is some sort of disruption of the carbon cycle, sometimes related to a slow geological process such as volcanism from sea-floor spreading, sometimes to an abrupt event such as a bolide impact. This strongly implicates OA and ocean anoxia as major drivers of mass extinctions [61] although direct geological evidence exists only for the end-Permian [62,63] and end-Triassic mass extinctions [64,65]. However, $p \mathrm{CO}_{2 \text { paleo }}$ is clearly implicated in four of the five greatest reef crises (not necessarily mass extinctions) of all time [66]. The best studied among the latter is the Paleocene-Eocene Thermal Maximum (PETM), where a peak of $p \mathrm{CO}_{2 \text { paleo, largely from }}$ methane [67], impacted the reefs of the Tethys [68], at that time the centre of coral diversity, causing a significant diversity reduction.

One long-term change in ocean carbonate chemistry with unclear relevance to OA is the alternation of 'calcite seas' (of low magnesium calcite) during greenhouse intervals with 'aragonite seas' (of high magnesium calcite and aragonite) during icehouse intervals. This change in the $\mathrm{Mg}^{2+} / \mathrm{Ca}^{2+}$ ratio of seawater is correlated with high levels of $\mathrm{pCO}_{2 \text { paleo }}$ as both are driven by changes in ocean crust production [69]. These secular changes in ocean carbonate chemistry correlate well with mass extinctions. During the end-Permian extinction, low magnesium calcite-secreting taxa (including all Palaeozoic corals) were replaced by aragonite-secreting taxa [57] among which were the first Scleractinia. During much of the Jurassic and on into the Cretaceous, seas again became calcitic and so did a significant proportion of the bivalve fauna of the time [70] including rudist bivalves (a major reef-builder of the mid-Cretaceous) and, curiously, at least one coral, Coelosmilia [71]. Indeed, two modern Mediterranean corals, Oculina patagonica and Madracis pharensis lose their skeletons when placed in highly acidified aquaria, then re-grow them when returned to normal seawater [72], a result in keeping with the intriguing 'naked coral hypothesis' where corals are proposed to live on, without skeletons, through geological intervals of OA [73].

\section{Conclusions}

The geological record leaves no doubt that OA has, in the past, devastated coral reefs. However, that record does not indicate what levels of $\Omega$ or $p \mathrm{CO}_{2}$ were involved, nor does it indicate the importance of rate of increase of $\mathrm{pCO}_{2}$ in the process. Furthermore, the fossil record does not indicate change in species diversity, the types of taxa most affected, or how these were affected.

OA impacts on coral reefs have been described as a sequence of degenerative changes within coral colonies or within coral communities and ecosystems [55,74-77]. Alternatively, impacts have been described in terms of a tipping point, when reef erosion exceeds reef accretion $[78,79]$. These views do not link closely with the reality of environmentally-driven change, dominated by synergies, and starting over a decade ago. Mass bleaching has seriously affected one-third of reefs worldwide, impacts that are mostly temporary for Acropora-dominated communities in otherwise healthy environments (as these have a return-time of a decade or less) but which are potentially permanent for communities dominated by slow-growing massive colonies. Increase in the frequency of mass bleaching events predicted to occur over the next 2-3 decades [75] will change this pattern: shallow-water communities will become populated by increasingly smaller colonies of the most rapidly recolonising species. These are changes in diversity, not abundance. Predicted increases in sea-level will probably have little effect on these communities other than to change zonation, but 
increases in storm and flood damage almost certainly will. Within this scenario, impacts from OA will be additional to changes brought about by other forms of environmental deterioration. They will not occur in isolation, nor will they affect only corals. Impacts on crustose coralline algae, an essential component of reef accretion, are particularly significant as calcification is either inhibited when exposed to prolonged but mildly acidified seawater [80,81] or increases up to a $\mathrm{pCO}_{2}$ of $600 \mathrm{ppm}$, then declines [28].

It is not possible to put a precise time-line of OA or identify the level of $p \mathrm{CO}_{2}$ that will initiate reef degeneration on a geological scale. During the entire Pleistocene, $\mathrm{pCO}_{2}$ remained $<280 \mathrm{ppm}$ giving the ocean surface a stable $\mathrm{pH}$ of 8.2. It now seems that OA, perhaps in synergy with temperature increase, may have been inhibiting coral growth since 1990 [82]. At a $p \mathrm{CO}_{2}$ of $\sim 450 \mathrm{ppm}$ (due to occur by 2035 a present rate of increase) the southern ocean will be undersaturated with respect to aragonite [83] after which OA will be seriously impacting the tropics. This will decrease biodiversity and increase rates of extinction. A $\mathrm{pCO}_{2}$ of $\sim 560 \mathrm{ppm}$ (due to occur around mid century) will cause a $20-60 \%$ decline in coral calcification $[19,76,84]$ and most reefs will enter a state of net dissolution [37]. Should $p \mathrm{CO}_{2}$ reach $\sim 630 \mathrm{ppm}$ (a realistic possibility as $\mathrm{pCO}_{2}$ and methane release will not be controllable by this stage) reef growth will cease completely [85]. Should $\mathrm{pCO}_{2}$ reach $\sim 780 \mathrm{ppm}, \mathrm{pH}$ will have decreased by $0.3-0.4 \mathrm{pH}$ units [86], the ASH will have reached the surface of all of the Southern Ocean south of $\sim 60^{\circ} \mathrm{S}$ and the average saturation states of all $\mathrm{CO}_{3}{ }^{2-}$ in surface water globally will be half present levels $[11,12]$. Should $\mathrm{pCO}_{2}$ reach $800 \mathrm{ppm}$ (still within the 21 st century) the decrease in ocean $\mathrm{pH}$ will have reached 0.4 units [87] and all reefs world-wide will be geological structures with none of the ecological characteristics we see today.

These changes, predicted to occur within a single century, are well in excess of any upheaval in any environmental parameter revealed during Pleistocene glacial cycles and are also in excess of any known geological event, even the PETM which occurred over a far longer time interval.

Fortunately, humanity appears to have moved on from crisis points like the political 'solution' of sequestration of $\mathrm{CO}_{2}$ effluent in the ocean. However, we have not moved far. Several international committees and organisations, each claiming a cloak of knowledge and responsibility, continue to target a $\mathrm{pCO}_{2}$ of $450 \mathrm{ppm}$ as a safe level for a stable earth. The big picture of reef science, which must inevitably become an amalgam of temperature and OA, argues strongly against this. Whether or not it is still possible to bring the earth back to any specific $p \mathrm{CO}_{2}$ level does not alter that science. A $p \mathrm{CO}_{2}$ $<350 \mathrm{ppm}$ [88] is what is required if reefs are to be maintained free of atmospheric degradation for the foreseeable future.

\section{Acknowledgments}

The author thanks Joanie Kleypas, Andrew Glikson, Paul Pearce-Kelley, Justin Ries, Terry Done, John Guinotte, Mary Stafford-Smith and Ray Berkelmans for their comments on the manuscript.

\section{References}

1. Skirrow, G.; Whitfield, M. The effect of increases in the atmospheric carbon dioxide content on the carbonate ion concentration of surface water at $25^{\circ} \mathrm{C}$. Limnol. Oceanogr. 1975, 20, 103-108.

2. Whitfield, M. Future impact of fossil $\mathrm{CO}_{2}$ on sea-Reply. Nature 1975, 254, 274-275. 
3. Broecker, W.S.; Takahashi, T. Neutralization of fossil fuel $\mathrm{CO}_{2}$ by marine calcium carbonate. In The Fate of Fossil Fuel in the Oceans; Andersen, N.R., Malahoff, A., Eds.; Plenum: New York, NY, USA, 1977; pp. 213-241.

4. Broecker, W.S.; Takahashi, T.; Simpson, H.J.; Peng, T.-H. Fate of fossil fuel carbon dioxide and the global carbon budget. Science 1979, 206, 409-418.

5. Feely, R.A.; Chen, C.-T.A. The effect of excess $\mathrm{CO}_{2}$ on the calculated calcite and aragonite saturation horizons in the northeast Pacific. Geophys. Res. Lett. 1982, 9, 1294-1297.

6. Feely, R.A.; Byrne, R.H.; Betzer, P.R.; Gendron, J.F.; Acker J.G. Factors influencing the degree of saturation of the surface and intermediate waters of the North Pacific Ocean with respect to aragonite. J. Geophys. Res. 1984, 89, 631-640.

7. Dickson, G.; Millero, F.J. A comparison of the equilibrium constants for the dissociation of carbonic acid in seawater media. Deep-Sea Res. 1987, 34, 1733-1743.

8. Kleypas, J.A.; Buddemeier, R.W.; Archer, D.; Gattuso, J.-P.; Langdon, C.; Opdyke, B.N. Geochemical consequences of increased atmospheric $\mathrm{CO}_{2}$ on coral reefs. Science 1999, 284, 118-120.

9. Plimer, I. Heaven+Earth, Global Warming, The Missing Science; Connor Publishing: Ballian, Australia, 2009.

10. Ridley, M. The Rational Optimist; Harper Collins: New York, NY, USA, 2010.

11. Orr, J.C.; Fabry, V.J.; Aumont, O.; Bopp, L.; Doney, S.C.; Feely, R.A.; Gnanadesika, A.; Gruber, N.; Ishida, A.; Joos, F.; et al. Anthropogenic ocean acidification over the twenty-first century and its impact on calcifying organisms. Nature 2005, 437, 681-686.

12. Fabry, V.J.; Seibel, B.A.; Feely, R.A.; Orr, J.C. Impacts of ocean acidification on marine fauna and ecosystem processes. J. Mar. Sci. 2008, 65, 414-423.

13. Doney, S.C.; Fabry, V.J.; Feely, R.A.; Kleypas, J.A. Ocean acidification, the other $\mathrm{CO}_{2}$ problem. Ann. Rev. Marine Sci. 2009, 1, 169-192.

14. Sabine, C.L.; Feely, R.A.; Gruber, N.; Key, R.M.; Lee, K.; Bullister, J.L.; Wanninkhof, R.; Wong, C.S.; Wallace, D.W.R.; Tilbrook, B.; Millero, F.J.; Peng, T.-H.; Kozyr, A.; Ono, T.; Rios, A.F. The oceanic sink for anthropogenic $\mathrm{CO}_{2}$. Science 2004, 305, 367-371.

15. Guinotte, J.M.; Orr, J.; Cairns, S.; Freiwald, A.; Morgan, L.; George, R. Will human-induced changes in seawater chemistry alter the distribution of deep-sea scleractinian corals? Front. Ecol. Environ. 2006, 4, 141-146.

16. Feely, R.A.; Sabine, C.L.; Byrne, R.H.; Greeley, D. Direct evidence for ocean acidification of the North Pacific Ocean. Pices 2006, 16, 22-26.

17. Feely, R.A.; Sabine, C.L.; Hernandez-Ayon, J.M.; Ianson, D.; Hales, B. Evidence for upwelling of corrosive "acidified" water onto the continental shelf. Science 2008, 320, 1490-1492.

18. Kleypas, J.A.; Feely, R.A.; Fabry, V.J.; Langdon, C. Impacts of ocean acidification on coral reefs and other marine calcifiers: A guide for future research. Presented at a Workshop Sponsored by NSF, NOAA, and the U.S. Geological Survey, St. Petersburg, FL, USA, 18-20 April 2005; UCAR: Boulder, CO, USA, 2006; pp. 1-96.

19. Kleypas, J.A.; Langdon, C. Coral reefs and changing seawater carbonate chemistry. In Coral Reefs and Climate Change, Science and Management Coastal and Estuarine Studies; American Geophysical Union: Washington, DC, USA, 2006; pp. 73-110. 
20. Reynaud, S.; Leclercq, N.; Romaine-Lioud, S.; Ferrier-Pagés, C.; Jaubert, J.; Gattuso, J.-P. Interacting effects of $\mathrm{CO}_{2}$ partial pressure and temperature on photosynthesis and calcification in a scleractinian coral. Glob. Change Biol. 2003, 9, 1660-1668.

21. Anthony, K.R.N.; Kline, D.I.; Diaz-Pulido, G.; Dove, S.; Hoegh-Guldberg, O. Ocean acidification causes bleaching and productivity loss in coral reef builders. PNAS 2008, 105, 17442-17446.

22. Langdon, C.; Atkinson, M.J. Effect of elevated $\mathrm{pCO}_{2}$ on photosynthesis and calcification of corals and interactions with seasonal change in temperature/irradiance and nutrient enrichment. $J$. Geophys. Res. Oceans 2005, 110, C09S07.

23. Langdon, C.; Broecker, W.S.; Hammond, D.E.; Glenn, E.; Fitzsimmons, K.; Nelson, S.G.; Peng, T.-H.; Hajdas, I.; Bonani, G. Effect of elevated $\mathrm{CO}_{2}$ on the community metabolism of an experimental coral reef. Glob. Biogeochem. Cycl. 2003, 17, 1011-1025.

24. Schneider, K.; Erez, J. The effect of carbonate chemistry on calcification and photosynthesis in the hermatype coral. Acropora Eurystoma. Limnol. Oceanogr. 2006, 51, 1284-1293.

25. Marubini, F.; Ferrier-Pagès, C.; Furla, P.; Allemand, D. Coral calcification responds to seawater acidification, a working hypothesis towards a physiological mechanism. Coral Reefs 2008, 27, 491-499.

26. Rodolfo-Metalpa, R.; Martin, S.; Ferrier-Pagès, C.; Gattuso, J.-P. Response of the temperate coral Cladocora caespitosa to mid- and long-term exposure to $\mathrm{pCO}_{2}$ and temperature levels projected for the year $2100 \mathrm{AD}$. Biosciences 2010, 7, 289-300.

27. Iglesias-Rodriguez, M.D.; Halloran, P.R.; Rickaby, R.E.M.; Hall, I.R.; Colmenero-Hidalgo, E.; Gittins, J.R.; Green, D.R.H.; Tyrrell, T.; Gibbs, S.J.; von Dassow, P.; Rehm, E.; Armbrust, E.V.; Boessenkool, K.P. Phytoplankton calcification in a high- $\mathrm{CO}_{2}$ world. Science 2008, 320, 336-340.

28. Ries, J.B.; Cohen, A.L.; McCorkle, D.C. Marine calcifiers exhibit mixed responses to $\mathrm{CO}_{2}$-induced ocean acidification. Geology 2009, 37, 1131-1134.

29. Wood, H.L.; Spicer, J.I.; Widdicombe, S. Ocean acidification may increase calcification rates, but at a cost. Proc. Roy. Soc. B 2008, 275, 1767-1773.

30. Tunnicliffe, V.; Davies, K.T.A.; Butterfield, D.A.; Embley, R.W.; Rose, J.M.; Chadwick, W.W. Survival of mussels in extremely acidic waters on a submarine volcano. Nat. Geosci. 2009, 2, 344-348.

31. Gattuso, J.-P.; Frankignoulle, M.; Bourge, I.; Romaine, S.; Buddemeier, R.W. Effect of calcium carbonate saturation of seawater on coral calcification. Glob. Planet Change 1998, 18, 37-46.

32. Langdon, C. Review of experimental evidence for effects of $\mathrm{CO}_{2}$ on calcification of reef builders. Proc. 9th Int. Coral Reef Sym. 2000, 2, 1091-1098.

33. Marubini, F.; Barnett, H.; Langdon, C.; Atkinson, M.J. Dependence of calcification on light and carbonate ion concentration for the hermatypic coral Porites compressa. Mar. Ecol. Prog. Ser. 2001, 220, 153-162.

34. Marubini, F.; Ferrier-Pagès, C.; Cuif, J.-P. Suppression of growth in scleractinian corals by decreasing ambient carbonate ion concentration, a cross-family comparison. Proc. Roy. Soc. B 2003, 270, 179-184.

35. Leclercq, N.; Gattuso, J.-P.; Jaubert, J. Primary production, respiration, and calcification of a coral reef mesocosm under increased $\mathrm{CO}_{2}$ partial pressure. Limnol. Oceanogr. 2002, 47, 558-564. 
36. Ohde, S.; Hossain, M.M.M. Effect of $\mathrm{CaCO}_{3}$ (aragonite) saturation state of seawater on calcification of Porites coral. Geochem. J. 2004, 38, 613-621.

37. Silverman, J.; Lazar, B.; Erez, J. Effect of aragonite saturation, temperature, and nutrients on the community calcification rate of a coral reef. J. Geophys. Res. 2007, 112, C05004.

38. Cohen, A.L.; McCorkle, D.C.; de Putron, S.; Gaetani, G.A.; Rose, K.A. Morphological and compositional changes in the skeletons of new coral recruits reared in acidified seawater, insights into the biomineralization response to ocean acidification. Geochem. Geophys. Geosyst. 2009, 10, Q07005.

39. Ries, J.B.; Stanley, S.M.; Hardie, L.A. Scleractinian corals produce calcite, and grow more slowly, in artificial Cretaceous seawater. Geology 2006, 34, 525-528.

40. Furla, P.; Galgani, I.; Durand, I.; Allemand, D. Sources and mechanisms of inorganic carbon transport for coral calcification and photosynthesis. J. Exp. Biol. 2000, 203, 3445-3457.

41. Cohen, A.L.; Holcomb, M. Why corals care about ocean acidification. Oceanography 2009, 22, $118-127$.

42. Venn, A.A.; Tambutté, E.; Lotto, S.; Zoccola, D.; Allemand, D.; Tambutté, S. Imaging intracellular $\mathrm{pH}$ in a reef coral and symbiotic anemone. PNAS 2009, 106, 16574-16579.

43. Brownlee, C. $\mathrm{pH}$ regulation in symbiotic anemones and corals, a delicate balancing act. PNAS 2009, 106, 16541-16542.

44. Chalker, B. Calcification by corals and other animals on the reef. In Perspectives on Coral Reefs; Barnes, D., Ed.; Clouston: Manuka, Australia, 1983; pp. 29-45.

45. Veron, J.E.N. Corals in Space and Time, the Biogeography and Evolution of the Scleractinia; University of New South Wales Press: Sydney, Australia, 1995.

46. Woodroffe, C.; McLean, R. Microatolls and recent sea level change on coral atolls. Nature 1990, 344, 531-534.

47. Hall-Spencer, J.M.; Rodolfo-Metalpa, R.; Martin, S.; Ransome, E.; Fine, M.; Turner, S.M.; Rowley, S.J.; Tedesco, D.; Buia M.-C. Volcanic carbon dioxide vents show ecosystem effects of ocean acidification. Nature 2008, 454, 96-99.

48. Fabricius, K.E.; Langdon, C.; Uthicke, S.; Humphrey, C.; Noonan, S.; De'ath, G.; Okazaki, R.; Muehllehner, N.; Glas, M.; Lough, J.M. Losers and winners in coral reefs acclimatized to elevated carbon dioxide concentrations. Nature 2011 (in press).

49. Guinotte, J.M.; Buddemeier, R.W.; Kleypas, J.A. Future coral reef habitat marginality: Temporal and spatial effects of climate change in the Pacific basin. Coral Reefs 2003, 22, 551-558.

50. Maier, C.; Hegeman, J.; Weinbauer, M.G.; Gattuso, J.-P. Calcification of the cold-water coral Lophelia pertusa, under ambient and reduced pH. Biogeosciences 2009, 6, 1671-1680.

51. Ries, J.B.; Cohen, A.L.; McCorkle, D.C. A nonlinear calcification response to $\mathrm{CO}_{2}$-induced ocean acidification by the coral Oculina arbuscula. Coral Reefs 2010, 29, 661-674.

52. Guinotte, J.M.; Orr, J.; Cairns, S.; Freiwald, A.; Morgan, L.; George, R. Will human-induced changes in seawater chemistry alter the distribution of deep-sea scleractinian corals? Front. Ecol. Env. 2006, 4, 141-146.

53. Fosså, J.H.; Mortenson, P.B.; Furevik, D.M. The deep water coral Lophelia perusa in Norwegian waters, distribution and fishery impact. Hydrobiologica 2002, 13, 1-2. 
54. Diaz-Pulido, G.; Harii, S.; McCook, L.; Hoegh-Guldberg, O. The impact of benthic algae on the settlement of a reef-building coral. Coral Reefs 2010, 29, 203-208.

55. Veron, J.E.N. A Reef in Time, the Great Barrier Reef from Beginning to End; Harvard University Press: Cambridge, MA, USA, 2008.

56. Kiessling, W.; Fluegel, E.; Golonka, J. Paleoreef maps, evaluation of a comprehensive database on Phanerozoic reefs. AAPG Bull. 1999, 83, 1552-1587.

57. Zhuravlev, A.Y.; Wood, R.A. Controls on carbonate skeletal mineralogy, global $\mathrm{CO}_{2}$ evolution and mass extinctions. Geology 2009, 37, 1123-1126.

58. Sepkoski, J.J., Jr. A Compendium of Fossil Marine Animal Genera; Paleontological Research Institution: Ithaca, NY, USA; 2002; pp. 1-563.

59. Kiessling, W. Phanerozoic reef trends based on the Paleoreefs database. In The History and Sedimentology of Ancient Reef Systems; Stanley, G.D., Ed.; Plenum Press: New York, NY, USA, 2001; pp. 41-88.

60. Wood, R. Reef Evolution; Oxford University Press: Oxford, UK, 1999.

61. Veron, J.E.N. Mass extinctions and ocean acidification, biological constraints on geological dilemmas. Coral Reefs 2008, 27, 459-472.

62. Knoll, A.H.; Bambach, R.K.; Canfield, D.E.; Grotzinger, J.P. Comparative earth history and Late Permian mass extinction. Science 1996, 273, 452-457.

63. Erwin, D.H. Extinction, How Life on Earth Nearly Ended 250 Million Years Ago; Princeton Universiry Press: Princeton, NJ, USA, 2006.

64. Hautmann, M. Effect of end-triassic $\mathrm{CO}_{2}$ maximum on carbonate sedimentation and marine mass extinction. Facies 2004, 50, 257-261.

65. Hautmann, M.; Benton, M.J.; Toma, A. Catastrophic ocean acidification at the Triassic-Jurassic boundary. N. Jb. Geol. Paläont. Abh. 2008, 249, 119-127.

66. Kiessling, W.; Simpson, C. On the potential for ocean acidification to be a general cause of ancient reef crises. Glob. Change Biol. 2011, 17, 56-67.

67. Zachos, J.C.; Röhl, U.; Schellenberg, S.A.; Sluijs, A.; Hodell, D.A.; Kelly, D.C.; Thomas, E.; Nicolo, M.; Raffi, I.; Lourens, L.J.; McCarren, H.; Kroon, D. Rapid acidification of the ocean during the Paleocene-Eocene thermal maximum. Science 2005, 308, 1611-1615.

68. Scheibner, C.; Speijer, R.P. Late Paleocene-early Eocene Tethyan carbonate platform evolution-A response to long- and short-term paleoclimatic change. Earth-Sci. Rev. 2008, 90, 71-102.

69. Ries, J.B. Geological and experimental evidence for secular variation in seawater $\mathrm{Mg} / \mathrm{Ca}$ (calcite-aragonite seas) and its effects on marine biological calcification. Biogeosciences 2010, 7, 2795-2849.

70. Hautmann, M. Shell mineralogical trends in epifaunal Mesozoic bivalves and their relationship to seawater chemistry and atmospheric carbon dioxide concentration. Facies 2006, 52, 417-433.

71. Stolarski, J.; Anders, M.; Przeniosło R.; Mazur M. A Cretaceous Scleractinian Coral with a calcitic skeleton. Science 2007, 318, 92-94.

72. Fine, M.; Tchernov, D. Scleractinian coral species survive and recover from decalcification. Science 2007, 315, 1811.

73. Stanley, G.D.; Fautin D.G. The origin of modern corals. Science 2001, 291, 1913-1914. 
74. Hoegh-Guldberg, O.; Mumby, P.J.; Hooten, A.J.; Steneck, R.S.; Greenfield, P.; Gomez, E.; Harvell, C.D.; Sale, P.F.; Edwards, A.J.; Caldeira, K.; Knowlton, N.; Eakin, C.M.; Iglesias-Prieto, R.; Muthiga, N.; Bradbury, R.H.; Dubi, A.; Hatziolos, M.E. Coral reefs under rapid climate change and ocean acidification. Science 2007, 318, 1737-1742.

75. Hoegh-Guldberg, O; Bruno, J.F. The impact of climate change on the world's marine ecosystems. Science 2010, 328, 1523-1528.

76. Guinotte, J.M.; Fabry, V.J. Ocean acidification and its potential effects on marine ecosystems. Ann. NY Acad. Sci. 2008, 1134, 320-342.

77. Anthony, K.R.N.; Maynard, J.A.; Guillermodiaz-Pulido, G.; Mumby, P.J.; Marshal, P.A.; Long, C.; Hoegh-Guldberg, O. Ocean acidification and warming will lower coral reef resilience. Glob.Change Biol. 2011, 17, 1798-1808.

78. Riebesell, U.; Körtzinger, A.; Oschlies, A. Sensitivities of marine carbon fluxes to ocean change. PNAS 2009, 106, 20602-20609.

79. Silverman, J.; Lazar, B.; Cao, L.; Caldeira, K.; Erez J. Coral reefs may start dissolving when atmospheric $\mathrm{CO}_{2}$ doubles. Geophys. Res. Lett. 2009, 36, L05606.

80. Langer, G.; Geisen, M.; Baumann, K-H.; Kläs, J.; Riebesell, U.; Thoms, S.; Young, J.R. Species-specific responses of calcifying algae to changing seawater carbonate chemistry. Geochem. Geophys. Geosyst. 2006, 7, Q09006.

81. Kuffner, I.B.; Andersson, A.J.; Jokiel, P.L.; Rodgers, K.S.; Mackenzie, F.T. Decreased abundance of crustose coralline algae due to ocean acidification. Nat. Geosci. 2008, 1, 114-117.

82. De'ath, G.; Lough, J.M.; Fabricius, K.E. Declining coral calcification on the Great Barrier Reef. Science 2009, 323, 116-119.

83. Neil, B.I.; Matear, R. Southern Ocean acidification, a tipping point at 450-ppm atmospheric $\mathrm{CO}_{2}$. PNAS 2008, 105, 18860-18864.

84. Langdon, C.; Takahashi, T.; Sweeney, C.; Chipman, D.; Goddard, J.; Marubini, F.; Aceves, H.; Barnett, H.; Atkinson, M.J. Effect of calcium carbonate saturation state on the calcification rate of an experimental coral reef. Glob. Biogeochem. Cycl. 2000, 14, 639-654.

85. Steinacher, M.; Joos, F.; Frolicher, T.L.; Plattner, G.-K.; Doney, S.C. Imminent ocean acidification in the Arctic projected with the NCAR global coupled carbon cycle-climate model. Biogeosciences 2009, 6, 515-533.

86. Caldeira, K.; Wickett, M.E. Ocean model predictions of chemistry changes from carbon dioxide emissions to the atmosphere and ocean. J. Geophys. Res. 2005, 110, C09S04.

87. Caldeira, K.; Wickett, M.E. Anthropogenic carbon and ocean pH. Nature 2003, 425, 394-395.

88. Veron, J.E.N.; Hoegh-Guldberg, O.; Lenton, T.M.; Lough, J.M.; Obura, D.O.; Pearce-Kelly, P.; Sheppard, C.R.C.; Spalding, M.; Stafford-Smith; M.G.; Rogers, A.D. The coral reef crisis, the critical importance of $<350$ ppm $\mathrm{CO}_{2}$. Mar. Pollut. Bull. 2009, 58, 1428-1436.

(C) 2011 by the authors; licensee MDPI, Basel, Switzerland. This article is an open access article distributed under the terms and conditions of the Creative Commons Attribution license (http://creativecommons.org/licenses/by/3.0/). 